\title{
Associated factors with resilience and burnout: a cross-sectional study in a teaching group in Spain
}

\author{
$M^{a}$. Inmaculada Vicente De Vera García, Ma Inés Gabari Gambarte
}

Universidad Pública de Navarra (España)

\begin{abstract}
Teachers are especially vulnerable to developing burnout. Resilience is the ability of people to overcome the difficulties of life. The objective of the study was to establish relationships between the perceptions of burnout and resilience in the surveyed group. The invited sample was composed of 334 teachers (26.34\% of the invited sample). It was a cross-sectional, descriptive and correlational study, which responded to a simple random sampling of 1268 teachers in the 2017/2018 academic year, through voluntary and anonymous participation. For the evaluation of burnout, the adaptation to Spanish (MBI-GS) of Salanova, Schaufeli, Llorens, Peiró and Grau (2000) was used. Resilience was measured through the Resilience Evaluation Questionnaire of Serrano Martínez (2010). High scores were found in personal/professional efficiency dimension that suggest a positive self-evaluation of work by teachers, and its influence as a protective factor against the feeling of being burned, only $2.40 \%$ with high exhaustion and cynicism and low efficiency score. The results showed a low burnout index and a medium level of resilience. It was concluded that resilience reduces vulnerability to burnout. Furthermore, the personal characteristics and resilience of teachers acted as modulating variables against the burnout syndrome.
\end{abstract}

Keywords: resilience; burnout; work stress; personal/professional efficiency; emotional intelligence.

\section{Factores asociados con la resiliencia y el burnout: un estudio transversal en un grupo de docentes en España}

\section{RESUMEN}

El profesorado es especialmente vulnerable a desarrollar burnout. La resiliencia es la capacidad de las personas para sobreponerse ante las dificultades de la vida. El objeto del estudio consistió en establecer relaciones entre las percepciones de burnout y resiliencia en el colectivo encuestado. Fue un estudio transversal, descriptivo y correlacional, que respondió a una muestra aleatoria simple de 1268 docentes en el año académico 2017/2018, a través de la participación voluntaria y anónima. Para la evaluación del burnout se empleó la adaptación al castellano del (MBI-GS) de Salanova, Schaufeli, Llorens, Peiró and Grau (2000). La resiliencia se midió mediante el Cuestionario de Evaluación de Resiliencia de Serrano-Martínez (2010). Se hallaron altos puntajes en la dimensión eficacia personal/profesional que sugieren una autoevaluación positiva del trabajo por parte del profesorado, y su influencia como factor protector contra la sensación de estar quemado, solo $2.40 \%$ con alto agotamiento y cinismo y bajo puntaje de eficacia. Los resultados mostraron bajo índice de burnout y nivel medio en resiliencia. Se concluyó que la resiliencia disminuye la vulnerabilidad al burnout. Además, las características personales y la resiliencia de los docentes actuaron como variables moduladoras frente al síndrome del burnout.

Palabras clave: resiliencia; burnout; estrés laboral; eficacia personal/profesional; inteligencia emocional. 


\section{Introduction}

Studies of burnout in the teaching staff show that the decrease in resources dedicated to teaching and curricular changes (Longas, Chamarro, Riera, \& Cladellas, 2012), work overload (Rodríguez, Sola, \& Fernández, 2017), temporary pressures (López \& Extremera, 2017), work disputes (Carlotto \& Câmara, 2017; Álvarez-Arregui y Arreguit, 2019), little degree of autonomy (Burgos, Paris, Salcedo, \& Arriagada, 2018), role dysfunctions (Peña \& Cantero, 2017), lack of role reciprocity (Fernández, 2017), among others, are related to the emotional fatigue of teachers (Llull, Cerdà, \& Pante, 2015; Berrocal, Cabello, \& Cobo, 2017). Moreover, the incidence of other external factors of the work environment, derived from the specific characteristics of the personality of the subject, family circumstances or the private and social life of the teacher, hinder the development of strategies of coping, which can lead to a decrease in their work, mental and physical activity, being the origin of disorders such as burnout (Fernández, Rivera, Pérez, \& Martínez, 2012; Murillo, Garrido, \& Hernández, 2016; Benetti, Goi, Dezordi, \& Benetti, 2018; Vicente de Vera \& Gabari, 2019).

Additionally, the motivation of the teacher must be combined with very diverse circumstances (professional and non-professional) that pose a problem as well as a challenge: the appearance of new functions, such as the use of ICTs and their teaching; attention to special educational needs or cultural diversity; challenges related to students, such as the need to solve behavioural and disciplinary problems, and the high levels of school dropout and failure (Gómez et al., 2010; León, Domínguez, Núñez, Pérez, \& Martín, 2011; Fernández, Rivera, Pérez, \& Martínez, 2012; Rodríguez, Hernández, \& Rodríguez, 2019).

In addition, it has been found that the same stressor agent does not cause the same effects in all individuals. Some subjects are more vulnerable than others to developing the syndrome, since this depends on the cognitive strategies that are available to solve problems, the type of professional exercise, and the development of protection factors linked to individual variables, such as the type of personality and attributes or features of it (Albar et al., 2004, Vargas, Niño, \& Acosta, 2017; Peña, Raso, \& Ferrero, 2018).

Among the individual resources that prevent the generation of burnout we find resilience, understood as: a dynamic process that involves a positive adaptation in contexts of great adversity (Luthar, Cicchetti, \& Becker, 2000: 543). The research states that resilience decreases vulnerability to burnout (Ornelas, 2016), with the ability to cope with stressors one of the key trends in resilience. In other words, the use of constructive coping strategies focused on the problem, prevents the development of the syndrome (Corrales, Valdés, Kienhelger, \& Hernández, 2012; Alarcón, 2018; Noreña, 2018). While the use of passive coping strategies focused on emotion, it facilitates its emergence (Aldás, 2017; Félix, García, \& Mercado, 2018). Burnout appears when coping strategies are focused on emotion and avoidance.

Recent studies underline that resilience improves or maintains professional efficiency (Rodríguez, Ramos, Ros, Fernández, \& Revuelta, 2016; Rodríguez, Guevara, \& Viramontes, 2017; Vallejo, 2017; Costales, \& Riaño, 2018). On the one hand, because the individual people perceive environmental demands as stressful and, on the hand, because they strive more. That is to say, the lack of self-confidence in doing well the tasks increases the probability of suffering burnout (Fernández, Rivera, Pérez, \& Martínez, 2012; Dios, Calmaestra, \& Rodríguez, 2018). These beliefs have shown their predictive potential in the development of the syndrome.
Emotional intelligence is another individual factor that explains that some people are more resistant to stressors because of their ability to perceive, understand and regulate both their emotions and those of others (González, González, \& San José, 2017; Vicente de Vera, \& Gabari, 2019). Renowned authors, such as Cassullo and García (2015) and Vélez, López and González (2017), point out that when teachers acquire emotional skills they are in a better position to interact with the students, he rest of the teachers and with the families.

The objective is to analyze the relationships between perceptions of burnout and resilience in a sample of 334 teachers from public High Schools. As a secondary objective, the goal is that, given the individual differences in the implementation of coping strategies faced with threatening situations, the personal characteristics and resilience of the person are two outstanding modulators of the well-being of the faculty of this study. Finally, we consider the influence that the emotional regulation, as well as the levels of effectiveness perceived by the collective surveyed, exert against burnout.

\section{Method}

\section{Design}

A transversal design is chosen, within a descriptive and correlational model. The independent variable is belonging to a High School teaching group.

\section{Dependent Variables:}

1. Burnout: syndrome of physical and emotional exhaustion, which implies the development of negative attitudes towards work, poor self-concept and loss of interest in the activities carried out. Three sub-variables: Exhaustion or emotional fatigue, Cynicism or depersonalization and Efficiency or personal fulfillment.

2. Resilience or positive adaptation to circumstances of significant adversity: an essential component for good work performance and a basic element for the protection of workers' welfare. Five sub-variables or dimensions: Sensitivity or emotional coping, Overcoming or behavioral coping, Positivism or naive optimism, Stereotyped thinking, and Tolerance to frustration.

\section{Participants}

The initial contact for the field study was carried out through an interview with the Management Teams of the selected Centers, belonging to the public education network during the $2017 / 18$ academic year, who valued the interest of the proposal and they contribute to the dissemination of the Questionnaire among the Cloisters, agreeing:

1. Sampling criteria: voluntary and anonymous participation of teachers, without identification of the educational center.

2. Online mode of data collection with a single shipment.

3. An active link for one month from the individual reception of the email, as latency time to issue the response. 
The invited sample was made up of professors from public high schools $(\mathrm{N}=1,268)$ in the $2017 / 18$ academic year. 14 surveys were excluded because they contained errors. The accepting sample consisted of 334 teachers $(26.34 \%)$, with the distribution set out below.

Table 1.

Sociodemographic distribution of the accepting sample

\begin{tabular}{|c|c|c|c|c|}
\hline Variables & Man & Woman & Total & Percentage \\
\hline $\begin{array}{l}\text { Between } 22 \text { and } 35 \\
\text { years }\end{array}$ & 12 & 30 & 42 & 12.57 \\
\hline $\begin{array}{l}\text { Between } 36 \text { and } 45 \\
\text { years }\end{array}$ & 44 & 64 & 108 & 32.34 \\
\hline $\begin{array}{l}\text { Between } 46 \text { and } 55 \\
\text { years }\end{array}$ & 62 & 68 & 130 & 38.92 \\
\hline $\begin{array}{l}\text { Between } 56 \text { and } 65 \\
\text { years }\end{array}$ & 28 & 26 & 54 & 16.17 \\
\hline Less than three & 8 & 4 & & \\
\hline years from & & & 12 & 3.59 \\
\hline Three to five years & 12 & 10 & & \\
\hline from & & & 22 & 6.59 \\
\hline Five to fifteen years & 26 & 70 & & \\
\hline between & & & 96 & 28.74 \\
\hline Fifteen and twenty & 28 & 26 & & \\
\hline years & & & 54 & 16.17 \\
\hline More than twenty & 78 & 72 & & \\
\hline years & & & 150 & 44.91 \\
\hline Official & 104 & 132 & 236 & 70.66 \\
\hline Hired & 16 & 20 & 36 & 10.78 \\
\hline Interim & 24 & 32 & 56 & 16.77 \\
\hline Substitute & 2 & 4 & 6 & 1.79 \\
\hline $\begin{array}{l}\text { Married or living as } \\
\text { a couple }\end{array}$ & 105 & 138 & 246 & 73.75 \\
\hline Single & 22 & 20 & 42 & 12.57 \\
\hline Others & 4 & 10 & 14 & 4.20 \\
\hline Empty & 12 & 20 & 32 & 9.58 \\
\hline No son & 44 & 68 & 112 & 33.53 \\
\hline A son & 30 & 44 & 74 & 22.15 \\
\hline Two children & 56 & 64 & 120 & 35.93 \\
\hline Three children & 14 & 10 & 24 & 7.19 \\
\hline $\begin{array}{l}\text { More than three } \\
\text { children }\end{array}$ & 2 & 2 & 4 & 1.20 \\
\hline
\end{tabular}

The distribution of the accepting sample was: 188 women (56.29\%) and 146 men (43.71\%). The highest percentage accumulated was between 46 and 55 years $(38.92 \%)$. Teaching exercise experience of more than twenty years (44.91\%). A high percentage $(70.66 \%)$ were civil servants. Also, $73.65 \%$ of teachers were married or living as a couple. As for the offspring, he highlighted the participation of teachers with children. $66.47 \%$ of the teaching staff had a child.

\section{Instruments}

Prior agreement with the Directors of the schools, the information collection instrument used was a single online ques- tionnaire of 55 items with a Likert response with five levels of response, with Cronbach's $\alpha$ reliability of .815 , which allowed us to state that. The collected data responded to the intended valuations, combining:

The MBI-GS General Services Burnout Inventory (Shaufeli et al., 1996) in the Spanish adaptation of Salanova, Schaufeli, Llorens, Peiró and Grau (2000). It consists of 15 items with a Likert response, on three scales of the construct: Exhaustion (5 items), Cynicism (4 items) and Efficiency (6 items). High scores in exhaustion and cynicism and low-efficiency scores mean "more burned by work". In the original version of the MBI-GS, its authors find Cronbach's alpha coefficients ranging from .84 to .90 for exhaustion, from .74 to .84 for cynicism, and from, .70 to .78 for professional efficiency. In its adaptation to Spanish, the reliability values of the scales according to Cronbach's alpha are .83 for exhaustion .73 for cynicism and .81 for professional efficiency.

Resilience was assessed through the Serrano Martínez Resilience Assessment Questionnaire (2010), with 34 issues structured on a Likert scale, with five levels of response from never (1) to always (5). The psychometric evaluation of the questionnaire showed 8 items as inconsistent, so they were eliminated. The exploratory factor analysis obtained five factors:

Factor I is Sensitivity or emotional coping (6 items), with strategies such as self-control, distancing, positive revaluation, self-incrimination and escape/avoidance. Factor II is the Overcoming or behavioral coping (8 items), which measures the tendency to think automatically in terms that facilitate effective action. Factor III is the Positivism or naive optimism (6 items), which includes aspects that refer to naive positivism or optimism and refers to the ability to think favorably, knowing how to emphasize the positive side of the situation. Factor IV, or Stereotyped thinking ( 4 items), is the tendency of some people to get carried away by socially established ideas. Finally, Factor V of Tolerance to frustration ( 4 items), measures the ability to face the problems and limitations that we encounter in life, despite the inconvenience or inconvenience caused to us.

Likewise, 4 questions collected information on sociodemographic variables: sex, age range, marital status and the number of children, and 2 other questions, on socio-labor variables of the teacher's job: seniority, stability (hired/am official/a, interim or substitute). It was decided not to request the identification of the workplace to avoid a decrease in the level of response, traditionally low on these issues.

\section{Process}

The management teams of the educational centers were contacted by telephone, requesting their collaboration to disseminate the questionnaire among teachers via email. A unique questionnaire was designed, and all invited teachers were sent along with the cover letter ensuring anonymity, as well as explaining that the objective that was intended to be obtained from data collection. A response receipt period of one month was established. The previous analysis was performed to rule out incomplete or erroneous questionnaires. Teachers participated voluntarily. All terms of the ethical guidelines of the Declaration of Helsinki (AMM, 2000) were respected at all times.

\section{Analysis of data}

The relationship between the scores and aspects measured between the different factors of the factorial extraction was measured by correlation coefficients. Only those variables that obtained correlation in values of $p>.20$ were included. In the study, 
the values of $r$ with a statistical significance of $p=.01$ were taken into account so that the results were sufficiently significant.

The statistical package SPSS version 23 was used for the descriptive, correctional and factorial statistical analysis of the information. The factorial structure of the scales was checked by exploratory factor analysis with Rotation of the Varimax type. Before performing the factor analysis, its adequacy was confirmed with the KMO index and the Barlett test.

\section{Results}

The highest score of the burnout scales is obtained in the dimension personal/professional efficiency with an average of $5.56(\mathrm{~s}=.83)$; then, the cynicism dimension with a mean of 3.41 $(\mathrm{s}=.94)$ and, finally, the emotional exhaustion dimension with a mean of $3.11(\mathrm{~s}=1.25)$.

The burnout questionnaire was corrected according to the Bresó, Salanova, Schaufeli, \& Nogareda (2007) manual, so that the values of the factors (exhaustion, cynicism and personal/ professional efficiency) were an average value. This operation was repeated for each of the scales and for each of the subjects to whom the measuring instrument was administered. Following the MBI manual, the assessments obtained indicated low burnout rates in the teaching staff of this study. Specifically, positive burnout rates were found below the 25th percentile. On the other hand, above the 25 th percentile $(n=92)$, positive efficiency values were obtained.

After analyzing the data, low burnout rates (percentile $<25$ ) were found in the group of participating subjects: 4 subjects with burnout $(2.40 \%$ of the sample) were clearly identified, diagnosed with high exhaustion and cynicism and low efficiency. It should be noted that all subjects have a mature age, a long career, 'security' in their job, which they had accessed by opposition; on the other hand, their sex and their family unit composition differ. There were also 14 cases $(7.18 \%$ of the sample) in which high depletion and cynicism were found with normal efficiency that led us to suspect that there could be more cases (see Table 2).

Table 2.

Teachers burnout evaluation

\begin{tabular}{rrl}
\hline$\%$ & $\begin{array}{l}\text { Burnout } \\
\text { index }\end{array}$ & Burnout cases \\
\hline 19.16 & $\mathrm{M}$ & No burnout with exhaustion $>5$ \\
10.78 & $\mathrm{M}$ & No burnout with cynicism $>5$ \\
8.38 & $\mathrm{M}$ & No burnout with exhaustion $>5$ and \\
& & cynicism $>5$ \\
7.18 & $\mathrm{U}$ & No burnout effectively $<4$ \\
$\mathbf{2 . 4 0}$ & $\mathrm{H}$ & Burnout syndrome \\
\hline
\end{tabular}

U: Under; M: Midle; $\mathrm{H}:$ High

The resilience questionnaire was corrected by finding for each of the five factors of the scale, first the sum and then the average of the questions that compose it. In order to know what percentage of the sample was resilient, the responses of this questionnaire were also corrected using percentiles. For this, the median was used, knowing that it corresponds to the 50th percentile. This indicated that there was a tendency to consider teachers who exceeded this median as possible resilients. After the analysis, the group of participating teachers was between the 25th and 75th percentile, in the middle category index of resilience. So the participating teachers were in the medium category of resilience index. The Table 3 shows the results of the sample in relation to the various resilience factors.

Table 3.

Evaluation of resilience in teachers

\begin{tabular}{lcc}
\hline Resilience factors & $\begin{array}{c}\text { Participants that } \\
\text { exceed the median in } \\
\text { each factor }\end{array}$ & $\begin{array}{c}\text { Percentage that } \\
\text { exceeds the medi- } \\
\text { an in each factor }\end{array}$ \\
\hline $\begin{array}{l}\text { Factor I: Emotional } \\
\text { coping }\end{array}$ & 182 & 54.49 \\
$\begin{array}{l}\text { Factor II: Behavioral } \\
\text { coping }\end{array}$ & 176 & 52.69 \\
$\begin{array}{l}\text { Factor III: Positivism } \\
\begin{array}{l}\text { Factor IV: Stereotyped } \\
\text { thinking }\end{array}\end{array}$ & 180 & 53.89 \\
$\begin{array}{l}\text { Factor V: Tolerance to } \\
\text { frustration }\end{array}$ & 168 & 50.30 \\
\hline
\end{tabular}

Of the total sample, 44 participants (26.34\%) obtained above-average scores on all five factors at once, and they were considered resilient.

On the other hand, through the factorial analysis of the single questionnaire (result of the union of the burnout and resilience questionnaire), 5 factors or components were obtained that evaluated aspects related to the work of the surveyed teachers. As stated in the following Table, these factors explained $47.74 \%$ of the total variance of the data. High reliability was obtained in most of the factors considered.

Table 4.

Reliability of the questionnaire and factors found in the factor analysis

\begin{tabular}{lccc}
\hline Dimensions & $\begin{array}{c}\text { Cronbach's } \\
\text { Alpha }\end{array}$ & $\begin{array}{c}\mathbf{N}^{\mathbf{0}} \\
\text { Items }\end{array}$ & \% Variance \\
\hline Factor I: Teaching Performance & .85 & 9 & 13.5 \\
Factor II: Work efficiency & .74 & 7 & 13.43 \\
Factor III: Negative aspects of work & .87 & 6 & 10.35 \\
Factor IV: Exhaustion & .91 & 6 & 6.49 \\
$\begin{array}{l}\text { Factor V: Achievements and cog- } \\
\text { nitions }\end{array}$ & .54 & 3 & 3.89 \\
\hline
\end{tabular}

\section{UNITED BURNOUT-RESILIENCE VARIANCE FACTORS}

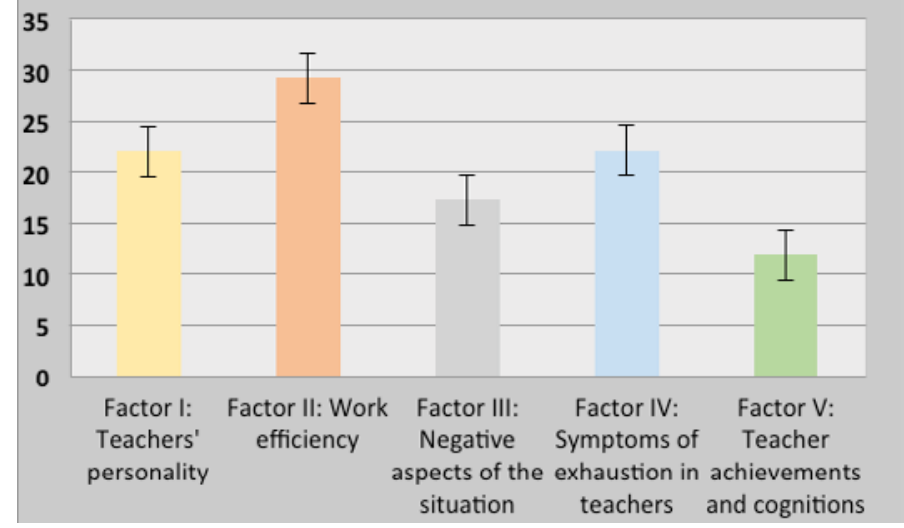

Figure 1. Graph of distribution of means and standard deviations in the factors of the single Questionnaire 
Correlational study of questionnaire factors includes the following results.

Table 5.

Correlational study of the factors

\begin{tabular}{lccccc}
\hline Factors & Factor I & Factor II & Factor III & Factor IV & Factor V \\
\hline Factor I & & -.38 & .56 & .56 & -.08 \\
Factor II & -.38 & & -.41 & -.22 & .38 \\
Factor & .56 & -.41 & & .77 & -.27 \\
III & & & & & \\
Factor & .56 & -.22 & .77 & & -.05 \\
IV & & & & & \\
Factor V & -.08 & .38 & -.27 & -.05 & \\
\hline
\end{tabular}

** Correlation is significant at level .01 (bilateral)

In addition, Table 6 presents the correlational study of the instruments applied in this study.

\section{Discussion}

The response rate obtained can be attributed to an attitude of fear or lack of interest to express issues related to burnout in this group and, in turn, maybe the reason why it is evidenced by the number of confirmed burnout cases. Authors/as Longas et al. (2012) report similar results in an investigation with teachers in Catalonia.

In the present study, teachers with a teaching experience of more than twenty years predominate, an aspect that can act as a protective factor given the safety provided by work experience, although it can also have negative repercussions in terms of loss of tuning.

It should be noted the low participation of the novel teaching staff. In this sense, authors such as Gómez et al. (2010) argue that the worker is more vulnerable to the syndrome in the first years of his professional career, since this is the period in which the transition from idealistic expectations to everyday practice occurs. Along the same lines, Rodríguez et al. (2019) corroborate that are teachers/young people who have higher levels of emotional exhaustion.

Likewise, the low participation of non-official teachers may be due, as Corrales et al. (2012), to which professionals suffer greater wear and tear with an eventual contract in services where the emotional impact is high, as is the case of teaching. Stands out the majority participation of women, married teachers and children. According to Albar et al. (2004) the fact of having chil- dren works as a protective factor against the syndrome, because it is related to the emotional support received by the family.

The low response rate may reflect a habitual tendency to under declaration in the field of psychosocial risk factors of the work environment and can be improved with the face-to-face collection of data or with the conduct of qualitative studies, through the use of interviews in-depth or use of narrative records such as daily or autobiographical (Rodríguez et al., 2017).

Likewise, high scores in the personal/professional efficiency dimension can be related to the positive self-assessment of work by teachers and that can act as a protective factor against the feeling of being burned.

As for the evaluations obtained in the components of the factorial analysis, the personality traits of the teachers evaluated in Factor I are a facilitating or inhibiting function in the development of the syndrome. The results corroborate the studies of Díaz et al. (2010), Ornelas (2016), Aldás (2017) and Félix et al. (2018), among others, who point out that the interaction between individual variables and the influences of the environment increases the possibility of producing stress and psychosocial mismatch in the person, but they also elevate the ability to respond effectively to adversity.

According to Rodríguez et al. (2016), Vargas et al. (2017), Alarcón (2018) and Noreña (2018), a resilient subject can remain stable even in the presence of conflicts, staying involved in the task and seeing these deficits as a challenge to overcome, without developing burnout. In short, the results of this factor confirm that the resilience of teachers decreases the vulnerability to burnout.

Factor II includes aspects that positively influence teacher performance. It is noted the contributions of Vallejo (2017) and Costales et al. (2018), who underline that, as the teacher's efficaciency decreases, feelings of emotional exhaustion and depersonalization increase, and tends to perceive environmental demands as stressful, which prevents you from seeing the positive aspects of the job. So, when a teacher perceives himself as a child, he is less likely to suffer from the syndrome, since the labor barriers have a minor impact (Fernández et al., 2012; Dios et al.; 2018). Thus, the levels of perceived efficiency found in this component protect the participating teachers against burnout.

On the contrary, Factor III agglutinates negative aspects of the teaching work. Some questions measure emotional exhaustion, others, the cynicism experienced. It is therefore a factor that measures burnout. In this context, Llull et al. (2015) affirm that most of the investigations on burnout point to the high school teachers as the most affected, especially in terms of depersonalization and personal fulfillment. Thus, the loss of emotional resources caused by the demands of teaching work (excessive

Table 6.

Correlations of burnout factors with resilience factors

\begin{tabular}{|c|c|c|c|c|c|c|c|c|}
\hline & Exhaustion & Cynism & Efficiency & Factor I & Factor II & Factor III & Factor IV & Factor V \\
\hline Exhaustion & 1 & $.58^{* *}$ & $-.24^{* *}$ & $.37^{* *}$ & $.20^{* *}$ & $.33^{* *}$ & $.61^{* *}$ & $-.58^{* *}$ \\
\hline Cynism & $.58^{* *}$ & 1 & $-.21^{* *}$ & $.30^{* *}$ & .06 & $.29^{* *}$ & $.47^{* *}$ & $-.48^{* *}$ \\
\hline Efficiency & $-.24^{* *}$ & $-.21^{* *}$ & 1 & $-.18^{*}$ & $.31^{* *}$ & $-.34^{* *}$ & $-.41^{* *}$ & $-.31^{* *}$ \\
\hline Factor I & $.37^{* *}$ & $.30^{* *}$ & $-.18^{*}$ & 1 & $.32^{* *}$ & $.56^{* *}$ & $.43^{* *}$ & $.50^{* *}$ \\
\hline Factor II & $-.20^{* *}$ & -.06 & $.31^{* *}$ & $.32^{* *}$ & 1 & $.19^{*}$ & .08 & $.26^{* *}$ \\
\hline Factor III & $-.33^{* *}$ & $-.29 * *$ & $.34^{* *}$ & $.56^{* *}$ & $.19^{*}$ & 1 & $-.41^{* *}$ & $.54^{* *}$ \\
\hline Factor IV & $.61^{* *}$ & $.47^{* *}$ & $-.41^{* *}$ & $.43^{* *}$ & $-.41^{* *}$ & .08 & 1 & $-.59^{* *}$ \\
\hline Factor V & $-.58^{* *}$ & $-.48^{* *}$ & $.31^{* *}$ & $.50 * *$ & $.26^{* *}$ & $.54^{* *}$ & $-.59^{* *}$ & 1 \\
\hline
\end{tabular}

*Correlation is significant at level .05 (bilateral). ${ }^{* *}$ Correlation is significant at level .01 (bilateral). 
number of students, excess of tasks, temporary pressures and overload of work, scarce support teachers, inadequate schedules, excessive bureaucracy, etc.), interact with the individual resources of the teacher, negatively impacting their health. These authors explain that negative interactions with pupils (frictions, conflicts and disputes) relate, on the one hand, positively with emotional exhaustion and depersonalization and, on the other, negatively with the low personal fulfillment. Likewise, the results confirm the investigations of Berrocal et al. (2017) and Peña et al. (2018) who report that the demands of students, companions and families cause emotional exhaustion in teachers. While depersonalization is expressed by emotional estrangement towards students and work companions.

Factor IV reflects symptoms of teacher exhaustion. In the educational field, emotional exhaustion refers to the loss of emotional resources caused by physical, mental, emotional and relational demands. Authors as Longas et al (2012), Fernández (2017), Peña and Cantero (2017) and Burgos et al. (2018) refer, the barrier factors (eg, role dysfunctions, absence or scarcity of resources, work overload, interpersonal conflicts, etc.), hinder the attainment of objectives, diminish in the teacher the feelings of self-efficacy and, with the time, they originate the syndrome. Rodríguez et al. (2017) and López and Extremera (2017) assert that labor overload also contributes to their appearance. Finally, Fernández (2012); Murillo et al. (2016), Carlotto and Cámara (2017), Benetti et al. (2018) and Vicente de Vera and Gabari (2019) report that the lack of organizational support causes emotional exhaustion in teachers and, therefore, influences the results of this component.

\section{Conclusions}

The results of this study allow establishing relationship levels between expressed burnout and resilience.

Some teachers are more vulnerable than others to burnout. In situations of adversity at work, the most resilient teachers achieve greater skills and competencies of commitment to work, while having the ability to overcome difficulties and adapt appropriately. While less resilient teachers are predisposed to increase their tiredness and indifference at work.

Likewise, personal variables determine the type of coping and the subject's response to stressors. It is concluded that resilience reduces vulnerability to burnout. Additionally, some personal variables (eg, humor, empathy, resistant personality, etc.) act as protective factors against burnout. From these lines, we emphasize the importance of developing resilience in teaching performance to face job demands, since it acts as a buffer for stressors and reduces vulnerability to burnout. We also insist that personal resources can be the object of the institutional approach of continuous training in the line of Prevention and Promotion of health in the educational field.

Furthermore, the results found show a positive association between resilience and the cognitive aspects of these professionals. Cognitions and emotions act as mediating variables in the relationship between perceived work stress and attitudinal and behavioral responses. The teacher who perceives himself as possessing a certain degree of ability to regulate his emotions, uses more active strategies to cope with stressful situations in the academic environment, and is in better conditions to relate to the students, the rest of the teaching staff and with families. In this sense, we highlight the importance that the development of emotional competences acquires, since they allow us to implement adequate coping strategies and improve support networks through adjusted social interaction.
Finally, the values found in this work highlight the value of efficiency as a mediator for motivation and the achievement of the goals of the teachers in this study. The positive aspects of work increase the teacher's perceived effectiveness, thus helping him to control stressful situations. Conversely, the negative aspects of the work diminish the teacher's feelings of effectiveness, hinder the achievement of objectives and, over time, lead to burnout. Therefore, the values found in this work highlight the value of efficiency as a mediator for motivation and achievement of the goals of the teachers in this study.

We consider that the findings in this study regarding burnout syndrome and resilience require the design of adequate research to know in more detail the implications that both constructs have in the work of these professionals.

\section{Limitations of the study}

The limitations of the study are associated with the cross-sectional design used, collecting data from the participants in a specific space-time that prevents causal relationships.

\section{Prospects for the future}

As a prospect for the future, in the first place, it would be interesting to carry out other longitudinal studies that would allow us to assess the evolution of the constructs studied over a longer period of time. Longitudinal studies provide more information about the syndrome development process, as well as the causal relationships between the different personal, social and labor factors with which it is linked. Frequently, the changes, quality and improvement that are requested of the education system are made in the midst of a lack of material, formal and personal resources to carry them out. In this situation, burnout syndrome is more than likely to be present.

Second, the context of this sample makes it difficult to generalize the reported data. In this sense, other educational stages such as Primary Education or Baccalaureate, Middle or Higher Education Degrees, as well as the university stage itself or adult education should be incorporated. It would be relevant to attend to other variables related to those studied, such as the typology of the educational center, as well as other psychological aspects such as engagement and teacher satisfaction.

\section{Practical implications}

Preventive and intervention actions should be aimed at reducing the risk of burnout which has implications for the well-being of these professionals.

According to the data obtained in this study, the positive aspects of the work increase the perceived effectiveness and this results in the fact that, in stressful situations, the teacher generates the coping resources necessary to control the demands of the situation. Consequently, the correct distribution of tasks and proper supervision helps teachers to face the problems arising from dealing with difficult students. This contributes, in turn, to deal more efficiently with the relationship with family members of students, or to better manage the work overload to which they are subjected, especially at specific times of the course (correction of exams, grades, etc.). In this way, it is involved in the prevention of symptoms related to the syndrome and, beyond the scope at the organizational level, it is possible to increase the teacher's life satisfaction. 


\section{References}

Alarcón, M. E. B. (2018). Stress and Burnout Diseases in Current Life. Palibrio.

Albar, M. J., Romero, M. E., González, M. D., Bayon, E., García, A., Gutiérrez, I., \& Algaba, S. (2004). Social support, socio-demographic characteristics and burnout in nurses and hospital auxiliaries. Nursing Clinic, 14(5), 281-285. doi.org/10.1016/ S1130-8621(04)73899-1

Aldás, A. C. (2017). Estrategias de afrontamiento y síndrome de burnout en personal de salud (thesis, Universidad Técnica de Ambato-Facultad de Ciencias de la Salud-Carrera de Psicología Clínica). Recuperado de:http://repo.uta.edu.ec/ bitstream/123456789/26500/2/Ana\%20Caroli na\%20Ald\%C3\%A1s\%20Villac\%C3\%ADs\%20pdf.pdf

Álvarez-Arregui y Arreguit, X. (2019). El futuro de la Universidad y la Universidad del Futuro. Ecosistemas de formación continua para una sociedad de aprendizaje y enseñanza sostenible y responsable. Aula Abierta 48, 4, 447-478. doi: https://doi.org/10.17811.rifie..48.4.2019.3447-478

Benetti, S. A., Goi, C. B., Dezordi, C. R., \& Benetti, M. (2018). Burnout syndrome in workers in prison. International Journal of Development Research, 8(07), 21992-21998.

Berrocal, P. F., Cabello, R., \& Cobo, M. J. G. (2017). Advances in research on emotional competencies in education. Inter-university Journal of Teacher Training, 88(1), 15-26.

Bresó, E., Salanova, M., Schaufeli, W. B, \& Nogareda, C. (2007). NTP No 732. Síndrome de estar quemado por el trabajo Burnout (III): Instrumento de medición. Madrid: Instituto Nacional de Seguridad e Higiene en el Trabajo, Ministerio de Trabajo y Asuntos Sociales.

Burgos, A.L.V., Paris, A.P.D., Salcedo, A.G.S., \& Arriagada, A. A. (2018). Psychological well-being and burnout in primary health care professionals in the region of Los Lagos, Chile. University Act, 28(3), 56-64.

Carlotto, M. S., \& Câmara, S. G. (2017). Psycho-social links associated with burnout syndrome in university professors. Advances in Latin American Psychology, 35 (3), 447-457. doi. org/10.12804/revistas.urosario.edu.co/apl/a.4036

Cassullo, G. L., \& García, L. (2015). Study of the Socio-Emotional Competencies and their Relationship with the Coping in Future Middle School Teachers. Interuniversity Electronic Journal of Teacher Training, 18(1), 213-228. doi.org/10.6018/ reifop.18.1.193041

Corrales, F. A., Valdés, B. C., Kienhelger, L. H., \& Hernández, J. S. (2012). Relaciones estructurales entre estrategias de afrontamiento y síndrome de burnout en personal de salud: un estudio de validez externa y de constructo. Universitas psychológica, 11(1), 197-206. doi.org/10.11144/Javeriana.upsy11-1.reea

Costales, A. F., \& Riaño, X. A. G. (2018). Satisfaction degree of English teachers of Preschool and Primary Education in the Principality of Asturias. Aula abierta, 47(4), 463-470. doi. org/10.17811/rifie.47.4.2018.463-470

Díaz, C. A. G., Tabares, S. J., \& Orozco, M. C. V. (2010). Burnout syndrome and coping strategies in primary and high school teachers. Psychology from the Caribbean, 26(1), 36-50.

Dios, I., Calmaestra, J., \& Rodríguez, A. J. (2018). Validation of the scale of organizational and didactic teaching competencies for educators. Mexican Journal of Educational Research, 23(76), 281-302.

Felix, R. O., García, C., \& Mercado ibarra, S. M. (2018). Stress in the workplace Generic review from the theory. CULCyT, 64(1), 31-42.
Fernández, M. P. (2017). Relationship between occupational wear and psychosomatic manifestations in a sample of Colombian teachers from the city of Santa Marta. Archives of Medicine (Manizales), 17(1), 78-90.

Fernández, R. A., Rivera, F. F., Pérez, M. N., \& Martínez, M. D. S. (2012). Efecto del sistema de enseñanza en el rendimiento académico, burnout experimentado y estrés académico. Aula abierta, 40(2), 3-10.

Gómez, C., Padilla, A., Rodríguez, V., Guzmán, J., Mejía, G., Avella-García, C. B., \& Edery, E. G. (2010). Influencia de la violencia en el medio escolar y en sus docentes: estudio en una localidad de Bogotá, Colombia. Revista Colombiana de Psiquiatría, 39(1), 22-44.

González, R. P., González, M. J. A., \& San José, C. C. (2017). Positive and negative affectivity in the future teacher: relations with their academic performance, mental health and satisfaction with life. Educational Contexts Journal of Education, 20(1), 11-26. doi.org/10.18172/con.2996

León, J., Domínguez, E., Núñez, J. L., Pérez, A., \& Martín, J. (2011). Translation and validation of the Spanish version of the Échelle de Satisfacción des Besoins Psychologiques in the educational context. Annals of Psychology, 27(2), 405-411.

Liu, J. Y., Liu, Y. H., \& Yang, J. P. (2014). Impact of learning adaptability and time management disposition on study engagement among chinese baccalaureate nursing students. Journal of Professional Nursing, 30(6), 502-510.

Llull, D. S., Cerdà, M. X. M., \& Brage, L. B. (2015). Social malaise and teacher discomfort: an investigation on burnout professional burnout syndrome and its socio-educational incidence. Classroom: Journal of Pedagogy of the University of Salamanca, 21(1), 245-257. doi.org/10.14201/aula201521245257

Longas, J., Chamarro, A., Riera, J., \& Cladellas, R. (2012). The incidence of the internal teaching context in the appearance of Burning Syndrome due to work in teaching professionals. Journal of Psychology of Work and Organizations, 28(2), 107-118. doi.org/10.5093/tr2012a9

López, S. M., \& Extremera, N. (2017). State of the issue on emotional intelligence and burnout in the teaching staff by countries, year of publication, educational cycles and evaluation instruments. Faculty, Journal of Curriculum and Teacher Training, 21(3), 371-389.

Luthar, S. S., Cicchetti, D., \& Becker, B. (2000). The construct of resilience: A critical evaluation and guidelines for future work. Child development, 71(3), 543- 562. doi.org/10.1111/14678624.00164

Mundial, A. M., \& Official Journal of the World Medical Association. (2000). Declaración de Helsinki. Principios éticos para las investigaciones médicas en seres humanos. 52a Asamblea General de Edimburgo, Escocia. Octubre de 2000. Revista Gaceta Médica de México, 137(4), 387-390.

Murillo, F. J., Garrido, C. M., \& Hernández, R. (2016). Decalogue for effective teaching. REICE. Ibero-American Journal on Quality, Efficacy and Change in Education, 9(1), 6-27.

Noreña, H. (2018). Estrés académico y estrategias de afrontamiento en estudiantes de primer, segundo y tercer semestre de la Facultad de Ingeniería de la Universidad de Antioquia, 2017 (Doctoral dissertation, Psicologia). Recuperado de http:/ /200.24.17.74:8080/ jspui/bitstream/fcsh/1138/1/Nore\%C3\%B1a Henry_2018_ Estr\%C3\%A9sAcad\%C3\%A9micoEstrategias\%20.pdf

Ornelas, P. E. (2016). Estrategias de afrontamiento y resiliencia en cuidadores primarios con duelo. Revista Psicología y Salud, 26(2), 177-184.

Peña, J. E., Raso, P. C. \& Ferrero, B. S. (2018). El síndrome de burnout en los docentes. Madrid: Ediciones Pirámide. 
Peña, S. B., \& Cantero, V. F. (2017). Ethnic prejudice and teacher attrition: a challenge in contexts of poverty. Electronic Journal of Educational Dialogues, 10(20), 14-39.

Rodríguez, A. M., Sola, T., \& Fernández, M. (2017). Impact of Burnout on the professional development of university teaching staff. A review of the investigation. Interuniversity Electronic Journal of Teacher Training, 20(3), 161-178. doi.org/10.6018/ reifop.20.3.275121

Rodríguez, A., Ramos, E., Ros, I., Fernández, A., \& Revuelta, L. (2016). Resiliencia e implicación escolar en función del sexo y del nivel educativo en educación secundaria. Aula Abierta, 44(2), 77-82. doi.org/10.1016/j.aula.2015.09.001

Rodríguez, C. L. C., Hernández, M. M. \& Rodríguez, T. C. (2019). Manifestaciones del Síndrome de Burnout, en docentes de la Universidad de Cienfuegos. Revista Conrado, 15(66), 91-97.

Rodríguez, J. A., Guevara, A. \& Viramontes, E. (2017). Síndrome de burnout en docentes. IE Revista de Investigación Educativa de la REDIECH, 8(14), 45-67.

Salanova, M., Schaufeli, W. B., Llorens, S., Peiró, J. M., \& Grau, R. (2000). From burnout to engagement: a new perspective? Journal of Psychology of Work and Organizations, 16(1), 117-134.

Schaufeli, W. B., Leiter, M. P., Maslach, C., \& Jackson, S. E. (1996). The Maslach Burnout Inventory: General Survey (MBI-GS). In C. Maslach, S., Jackson \& M. Leiter (eds.): Maslach Burnout Inventory Manual, 3rd ed. (pp. 19-26). Palo Alto, California: Consulting Psychologists Press.
Serrano, M. (2010). Construcción y análisis psicométrico de un cuestionario de evaluación de la resiliencia. Material de Grado en Psicología. Unizar.es. [recuperado28/01/2015]Disponible en: www. unizar.es/abarrasa/tea/200910_25906/serrano2010.pdf]

Vallejo, M. (2017). An approach to the burnout syndrome and the labor characteristics of Spanish emigrants in European countries. Journal of Psychology of Work and Organizations, 33(2), 137-145. doi.org/10.1016/j.rpto.2017.02.001

Vargas, L. D., Child, C. L., \& Acosta, J. Y. (2017). Strategies that modulate the Burnout syndrome in nurses (as): a bibliographic review. Science and Care Magazine, 14(1), 111-131. doi. org /10.22463/17949831.810

Vélez, A. P., Lopez, J. J., \& Gonzalez, J. B. (2017). Emotional skills and teacher professionalization for inclusive education in the networked society. Educational Contexts Journal of Education, 20(1), 201-215. doi.org/10.18172/con.3011

Vicente de Vera García, M. I., \& Gambarte, M. I. G. (2019). Emociones positivas: una herramienta psicológica que contribuye al proceso de resiliencia en los profesionales de la educación. Revista INFAD de Psicología. International Journal of Developmental and Educational Psychology, 4(1), 159-172.

Vicente de Vera García, M. I., \& Gambarte, M. I. Gabari (2019). Relationships Between the Dimensions of Resilience and Burnout in Primary School Teachers. International Electronic Journal of Elementary Education, 12(2), 189-196.doi.org/10.26822/ iejee.2019257666 